\title{
Editorial: For a Time Like This
}

This edition of the International Journal of Public Theology wrestles with the vocation of the discipline in demanding times. The past couple of years have been dominated by the CoviD-19 pandemic and the premature talk, perhaps, of a 'new normal'. The pandemic cannot hide other pressing matters forever, though. The spectre of cataclysmic climate change looms ever larger - a significant reality for some folk already as the book review dedicated to the IPCC Special Report on the Ocean and Cryosphere indicates. How the Christian faith and Islam relate to one another is likewise a critical concern, given the proportion of the world's population that adhere to these two traditions. Nor can a pandemic mask the problems that arise out of the forces that lead to a post-truth mentality and politics - not to mention the power of multinational corporations over the lives of individuals. In the midst of so much upheaval western churches are often needing to come to terms with their decline in societies in which they were once a formative public presence while the need for a theoretical basis of a public theology is always ever-present. Beyond covid there is a miscellany of issues facing a public theology for a time like this.

In view of COP 26 taking place in Glasgow it seemed timely to lead this edition of the journal with an article on climate change. The deepening recognition of the importance of the 'emotionologies' of what is involved here is represented by Andrew Shepherd's focus upon evolutionary psychology. The underlying issue is what kind of messaging can trigger human behavioural change. Is it fear of the future coupled with images of terror? Or is it a turn to hope (which needs to be wary of being confused with a facile technocratic optimism?). Shepherd argues that the play on fear and terror resonates with the apocalyptic mood of Matthew 24. The possibility of an alternative future that imagines a different kind of future can be stimulated by the practice of preaching and singing.

Ben Myers revisits the well-researched interrelationship that exists among and between the church, the academy and the public domain. For some these days kairos moments like climate change is likely to suggest that a public theology has a role to play in transdisciplinary lines of approach. Myers prefers to take a different tack. He turns to Schleiermacher's perspective on theology being a practical science intended for Christian leadership in society. Taking 
this line of approach effectively means that the purpose of theology in the academy is not so much one of its complementary role to other disciplines. Myers is writing out of his own experience in the Australian context where theological institutions are, more often than not, denominational in nature, in ecumenical associations and sometimes in partnership agreements with universities. Myers argues that this particular ecclesial orientation to theology does not compromise the prospects for a public theology: the grounds for that claim lie in his conviction that service to the Christian community is a means by which the common flourishing of society.

One of the distinguishing features of recent public theology has been the number of articles coming out of Nigeria. The most common theme is what ought to be the response of a public theology to the violence occurring in the north between Muslim and Christian. Ever mindful of the risk of a cycle of reprisals Isuwa Atsen addresses the question whether it is right to use violence in response to an unsolicited attack. The harrowing situations lying before Atsen concern the violence done to the innocent, especially women and children. What he is wrestling with is, in effect, how can a public theology discern a way forward in such a matter of life and death. The clear tension is how to negotiate a way through the teaching of Jesus to love one's enemies and the existential realities of violent attack. Through close attention to the sermon on the mount and the implicit ethical tendencies of the New Testament Atsen makes the case for the a phronetic deployment of a measured violence for purposes of self-defence.

In a time of climate change how the Christian faith and Islam relate to one and how they can work together for the common good is of paramount interest. Stephen Pickard is able to respond to this relationship between the two largest religions in the world at a remove from the hostilities in Nigeria and those arising elsewhere. At first glance it may seem odd that Pickard should select the theology of Karl Barth for the sake of both a public theology and then one which engages with Islam. Pickard examines the theological concepts of divine simplicity and the attributes of God. In a manner of speaking he is addressing theological foundations. Pickard believes that a public theology must take seriously the relationship between theory and practice in interreligious dialogue.

Writing out of Hong Kong Ben Siu-pun Ho is concerned with the nature of the theological response to the rise of terms like 'post-truth', 'fake news' and 'alternative facts'. These terms are not neutral: they influence policy and popular opinion as has been evident in the Trump presidency, the Brexit referendum, the Chinese response to the plight of the Uighurs and the Hong Kong 
protests. Ho negotiates his way through two types of theological response in order to arrive at the possibility of what Adam Pryor has defined the need for a 'public theology for a post-truth society'. The first of those approaches is inclined to be one that is rather condemnatory and sets 'God's truth' over and against the post-truth phenomenon. The second is more interested in the factors which underpin the plausibility of what can be shown to be a partial truth and fake. What fears, anxieties and 'wounds' lead to this selectivity of what to believe to be true? What ideological factors drive the politics that seek to benefit from the manipulation of truth and transparency? Ho perceives the need for a third way that brings the theological concern for truth into conversation with the reasons behind the lure of the 'cave of manufactured facts'. The theological response he proposes lies in his appropriation of Paul Tillich's understanding of 'ultimate concern'.

Following in the wake of other articles on churches and faith-based organizations at work in the public domain Richard Wilson examines the idea and practice of hybridity. The case studies that lie behind Wilson's empirical approach to a public theology are taken from a denominational church showing signs of decline in numbers and influence. The merit of a hybrid church in this context is how it can create a place and a role in the secular domain through the adoption of some business practices. Wilson is well-suited to this task given his familiarity with an extensive range of writings on 'theories of hybrid organizations' and 'institutional logics'. Of particular interest is the emphasis placed upon the themes of hospitality and embassy. Under the influence of the former the hybrid church seeks to create an alternative space to what the institutional church can offer that allows for a plurality of voices and participation. This space can be provided for through the invocation of values around ideas of social justice and equity. Wilson suggests that the accent on embassy presumes less need to be constrained by historical positions and more open to the formation of other spaces and occupying an 'alternative identity'. The hybrid model provides the church with an ongoing opportunity to shift culture, influence organizations and structures and mof|dify patterns of engagement.

Most often a public theology seems to deal with issues and perspectives that refer to communities of interest. The very idea of the common good seems to suggest such. In her reading of the precarity of the human body Hee-Kyu Heidi Park employs a case study of a one-person protest against a multinational conglomerate on a CCTV pole in Seoul. The protest is a public spectacle in a way that writings and recordings are not: it is visible to bystanders; it is a public spectacle. How should such an act be interpreted? There are biblical 
resonances alongside postures that can be understood through a culture's 'repertoire of contention' - in this case, a seemingly suicidal protest. Park's work is of an interdisciplinary nature involving an enquiry into acts of communication, theories of torture and abuse and psychotherapy. It exposes the power of corporations, the malevolent impact on individuals, and the imaginative response of church supporters in the bid to negotiate a just end.

Clive Pearson | ORCID: 0000-0003-2557-7562

Editor-in-Chief

Research Centre for Public and Contextual Theology,

Charles Sturt University, Australia

cpearson@csu.edu.au 